\title{
A SHIPOWNER'S RIGHT TO LIMIT LIABILITY IN CASES OF PERSONAL CONTRACTS
}

\author{
WEARTON POOR \\ New York Bar
}

A principle as old as the law itself is that a shipowner does not incur liabilities exceeding the value of his ship and her pending freight. Mr. Justice Holmes, in his well-known book The Common Law, traces the principle to the theory of deodand or noxae deditio,- - that by surrendering the guilty thing, the owner became free from all personal liability. Whether the one rule grew from the other, or whether the resemblance between the two is a mere coincidence need not be discussed here. Suffice it to say that the right of a shipowner to limit his liability is recognized in some form or other by the maritime law of all nations. Whether this is wise under present conditions is again a question with which this article is not concerned. The most satisfactory argument in favor of the right to limit liability is that sea adventures are peculiarly liable to mishaps of appalling extent; that the owner "blameless but powerless" must entrust his ship to servants who, no matter how carefully selected, may by a moment's inattention or carelessness, cause disaster; that in view of these considerations, investment in shipping would be discouraged if unlimited liability were thrown upon shipowners. On the other hand, the fact that an owner's liability is limited to the value of his ship must inevitably lessen the degree of care employed by him in the selection of his crew and in other respects tending to secure safety in navigation. And this is the more regrettable for the reason that an inefficiently manned and equipped vessel is a menace not only to herself and her cargo, but to every other craft that sails the seas. As the law now stands a shipowner may rest secure if he has used ordinary care in appointing properly.certificated officers and a qualified crew; yet a few moments' faulty navigation on their part may result in the sinking of a passenger liner and the loss of hundreds of lives.

The right of limitation of liability rests upon statutory authority both in England and this country.

The first English statute was passed in I734 and limited the owner's liability for embezzlement and theft by the master and mariners to the value of the ship and her freight for the voyage. ${ }^{1}$ The right to limit liability was extended by subsequent statutes until in Ig0o it was made to include cases where, without the owner's actual fault or privity, "any loss or damage is caused to property

\footnotetext{
I7 Geo. II, c. I5.
} 
or rights of any kind, whether on land or on water, or whether fixed or movable, by reason of the improper navigation or management of the ship." The most important difference between English law and that of the United States is that by the law of England the owner must surrender $\ell_{I} 5$ per ton in cases of loss of life or personal injury and $£ 8$ per ton in respect to other claims. As in the United States, the owner cannot limit his liability if he has been personally at fault. The right to limit liability may be waived by contract. ${ }^{3}$

The right to limit liability was first introduced in the United States by an Act of Congress of March 3, 1851.4 The provisions of this Statute have now been incorporated in the Revised Statutes, section 4283 of which comprehensively defines the instances in which limitation of liability may be had: ${ }^{5}$

"The liability of the owner of any vessel, for any embezzlement, loss, or destruction, by any person, of any property, goods, or merchandise, shipped or put on board of such vessel, or for any loss, damage, or injury by collision, or for any act, matter, or thing, lost, damage, or forfeiture, done, occasioned, or incurred, without the privity, or knowledge of such owner or owners, shall in no case exceed the amount or value of the interest of such owner.in such vessel, and her freight then pending."

If the draftsman of this statute cannot be congratulated on the elegance of the diction, it must at least be conceded that the end apparently sought has been attained. The statute has always been broadly interpreted by the courts and, it is believed, is construed to cover every possible kind of damage that may be done by a ship. This is chiefly for the reason that the Supreme Court has taken the view that the effect of the statute was to adopt as a part of our jurisprudence the ancient rule of the sea that a shipowner's risk was limited to his stake in the venture. As said by Mr. Justice Bradley in Norzeich Company v. Wright: ${ }^{8}$

"But it will be observed that the act of Congress contains a provision for the ship-owner to discharge himself, as in the maritime law, by giving up the vessel and her freight. This provision is not contained in any of the English or State statutes, and could not have been inserted in the act of Congress without direct reference to the like provision of the maritime codes. Could it have been inserted for any other purpose than to adopt the rule of that code? This is a question of much interest and importance.

"We do not hesitate to express our decided conviction, that the rule of the maritime law on this subject, so far as relates to torts, was intended to be adopted by the act of I85x."

${ }^{2}$ Carver, Carriage of Goods by Sea (6th ed. I9r8) sec. 26.

${ }^{3}$ The Satanita [1897, H. L.] A. C. 59.

${ }^{4} 9$ Stat. at L. 635 .

${ }^{5}$ Revision of 1878 .

' (I877, U. S.) ז3 Wall. I04, I26-127. 
In $x 884$ Congress passed another statute which, as will be seen, has led to much difficulty. This act reads :

"The individual liability of a ship-owner shall be limited to the proportion of any or all debts or liabilities that his individual share of the vessel bears to the whole; and the aggregate liabilities of all the owners of a vessel on account of the same shall not exceed the value of such vessel and freight pending."

It was at first argued that under this statute a shipowner could run up bills to an unlimited extent and then release himself from all liability by surrendering his vessel, or what remained of her, to his creditors. It was soon decided, however, that this statute must be construed in pari materia with the provisions of the revised statutes; that each voyage must be considered as a unit and that a shipowner could not run his ship for an indefinite period and then wipe out all past liabilities by taking advantage of the statute. ${ }^{8}$ It was further decided that the statute did not apply to debts personally incurred by the shipowner, or authorized to be contracted by him, but only to such as he was made liable to by operation of law. ${ }^{9}$ It is obvious that the statute, when thus limited, could be of little, if any, benefit to the shipowner. It did, however, indirectly, enable him to limit his liability for non-maritime torts which previous to the Act of $1884^{10}$ had been held not to be within the scope of the Limitation of Liability Acts. ${ }^{11}$

An important case, where the shipowner unsuccessfully attempted to limit his liability against a claim based on contract, is Great Lakes Towing Co. v. Mill Transportation Co. ${ }^{12}$ There the towing company had entered into a contract with the transportation company, the contract being signed by the manager of the transportation company, by which the towing company agreed to do towing and salvage work for the transportation company at specified rates. One of the steamers of the transportation company having gone ashore, the towing company was requested to go to its assistance. Services were rendered by the towing company, but before the vessel could be brought to port she sank and became a total loss. In an action brought by the towing company to recover compensation for the services, the transportation company attempted to limit its liability. The Court held that the contract under which the services were rendered was the personal contract of the transportation company and hence not subject to limitation. The actual decision is possibly not objectionable, but in some of the language used the Court went far afield, saying: $:^{13}$

\footnotetext{
${ }^{7} 23$ Stat. at L. 53,57 , sec. 18.

${ }^{3}$ The Puritan (1899, N. D. I11.) 94 Fed. 365.

Rudolf v. Brozen (1905, S. D. N. Y.) I37 Fed. 106.

${ }^{10}$ Supra note 7.

${ }^{21}$ Richardson v. Harmon (I9II) 222 U. S. 96, 32 Sup. Ct. 27.

${ }^{12}$ (1907, C. C. A. 6th) I55 Fed. II. ${ }^{13}$ Ibid. 16.
} 
"It seems to us altogether unlikely that Congress intended to qualify the power of an owner to make contracts in relation to his ship which by the universal law would be valid if made about any thing else and would be enforced in the courts in common-law actions. It would be an anomaly that a party competent to do business should be unable to make a valid contract about his own affairs, or be given such an immunity as to make his stipulations of uncertain value. Such a doctrine would be inconvenient in the last degree to the owners of vessels and the interests of commerce. If in every case the party who should undertake to render assistance to other vessels on request of the owner should be dependent on the proceeds of the vessel for his compensation, he would be likely to consider the chances, and the sorer the need of the services the less likely would the owner be to secure them. Instead of relieving him of a burden, he would be burdened with the disability of pledging his personal credit for the securing of the needed assistance."

Surely it is altogether erroneous to say that the Limitation of Liability Acts prevent a shipowner from assuming full liability for a loss. The right to limit liability is the shipowner's personal privilege, which he may waive if he so desires, and this waiver may be effected by contract or possibly in other ways. Whether or not the right to limit is waived by a contract is a question of construction, and it may be that the Court reached a correct conclusion, though the reasoning on which the result is based is open to exception.

In The Loyal, ${ }^{14}$ a lighterage company had made a contract to furnish lighters for lighterage services in New York harbor. One of the lighters sank because of its unseaworthy condition. It was held by a majority of the Court that the lighterage company was not entitled to limit its liability though it was not "privy" to the unseaworthiness. The decision is put on the ground that the contract was a personal one, and was subject to an implied term that the lighters were to be seaworthy. One of the judges dissented from this view, but concurred in the result on the ground that privity was shown.

In Benner Line v. Pendleton, ${ }^{15}$ a sailing vessel had been chartered to carry a cargo from New York to the West Indies, the charter containing the usual clause that the vessel was "tight, staunch, strong." Soon after sailing the vessel, from some unexplained cause, filled and sank. The Court found that the sinking was due to unseaworthiness, but there was no finding of "privity" on the owner's part. Nevertheless the right to limit liability was denied. The Circuit Court of Appeals said :16

"It seems to us that the distinction which the courts have drawn relates to the manner in which the contract is made, rather than to the character of the contract itself. The rule which has been established is that the shipowner may limit his liability as to contracts or obligations entered

\footnotetext{
${ }^{14}$ (19r3, C. C. A. 2d) 204 Fed. 930.

${ }^{15}$ (I9r4, C. C. A. 2d) 217 Fed. 497 , affirmed by the Supreme Court sub nomine Pendelton v. Benner Line (rg18) 246 U. S. 353,38 Sup. Ct. 330.

${ }^{16}$ 217 Fed. at p. 507 .
} 
into by others on his behalf, or imputed to him by law; but he may not limit his liability upon contracts which he personally makes or upon obligations which he personally assumes. If the particular contract is made by the shipowner in person, it is a matter of no consequence, so far as the question now under consideration is concerned, whether it relates to and binds a particular vessel or not.

'By a 'personal contract' we understand to be meant a contract made by the person or corporation to be bound as distinguished from one imputed to such person or corporation. In Great Lakes Towing Co. v. Mill Transportation Co., supra, the court said:

'The contracts of the manager are the actual contracts of the owner, and are not of the same character as the contracts of the master made on a voyage or in foreign ports, and which are imputed to the owner from the necessities of commerce. The acts of the managing agent within the sphere of authority are as much the acts of the owner as if done by the owner himself. Only upon this theory could a corporation make what, for the purpose of making a distinction, is called a personal contract; that is to say, one which the owner himself or itself has made.'

"The argument has been advanced that the contract herein involved is in no way the personal contract of the respondent, and that no accident of signature either to the charter party or the bill of lading can make it a personal contract. It is said that it is such a contract as is incident to the ownership of vessels. But this is a case where the managing owner of a vessel personally negotiated and signed the contract, charter party, which contained a provision that the vessel should be 'tight, staunch, strong and in every way fitted' for the voyage. It purported to be made between the libelants and Pendleton Bros., agents of the schooner Edith Olcott; and was signed, 'Pendleton Brothers, Benner Line.' As the respondent, the principal owner of the vessel, personally signed it as his own agent, he bound himself. The fact that it was the ordinary case of a charter party binding the ship does not prevent its being the personal contract of Pendleton Bros."

The language here used suggests interesting possibilities. Most contracts for carriage by sea are signed by the owners personally or by duly authorized agents,- -for instance, passenger tickets. There can be no question but that a passenger on the ill-fated Bourgogne who had suffered personal injuries or lost his luggage could have sued the owners for breach of contract. If the remarks of the court in the Pendleton case are to be taken at their full value, such an action would not have been subject to limitation. Nevertheless, limitation was in fact allowed, perhaps because the passengers proceeded on the wrong theory.

In The Julia Luckenbach, ${ }^{17}$ the steamer Julia Luckenbach had been time chartered by her owners to the Insular Line. The Insular Line in turn chartered the vessel to carry a cargo of sugar from Cuba to New York. Owing to a corroded condition of the vessel's hull,

${ }^{17}$ (19r6, C. C. A. 2d) 235 Fed. 388, affirmed Luckenbach v. McCahan Sugar Ref. Co. (1918) 248 U. S. 139, 39 Sup. Ct. 53. 
sea-water came in and damaged the sugar to the amount of $\$ 100,000$. The cargo owners sued the Insular Line to recover this loss, and the Insular Line impleaded the owners. The defect in the vessel would have been discovered if due diligence had been used, but there was no "privity" on the owner's part. The Insular Line was clearly liable for the full amount, and the chief question was whether the owners could limit their liability to $\$ 60,000$, the value of the Julia Luckenbach. In the charter to the Insular Line, the owners of the Julia Luckenbach agreed to maintain the steamer "in a thoroughly efficient state in hull and machinery." It was held that this constituted a personal contract for the breach of which the owners of the steamer were liable without limit. Even owners who had not signed the charter at all were held liable without limit because they had authorized what was done.

The broad language of some of these decisions has been somewhat limited by the recent decision of the Circuit Court of Appeals in The Ice King. ${ }^{18}$ In that case some barges were lost through the negligence of the crew of a tug which had been employed to tow them to sea. Privity on the part of the tugowner was not shown. The court said: $:^{19}$

"If there was a warranty in this case, it was implied, and of course, if it is to be given the same effect as an express warranty, the owners are liable, whether at fault or not, and whether exercising due diligence or not.

"We know of only one decision as to such implied warranty in proceedings to limit liability, and that related to a contract for the carriage of goods. ${ }^{20}$ A contract of towage imposes, not the duty of an insurer, but only the duty of exercising ordinary care and skill. Assuming, however, that such an implied warranty does exist in a contract of towage; how far does it extend? Are the owners, having furnished a sufficient and competent crew, with officers duly licensed as required by law, to be held liable for such subsequent arrangements as were made in this case, and for the subsequent intoxication of the pilot while on the trip? To extend such a warranty in this way would go far to nullify the wholesome purposes of the law."

A shipowner's right to limit liability against claims based on contract has also come before the English courts. In London and Southrestern $R y$. Co. v. James, ${ }^{21}$ the Railway Company had brought proceedings to limit its liability as owner of the steamer Normandy which had been lost in a collision for which it was solely to blame. James was a passenger who was suing for the loss of his luggage. He had bought a through ticket from Waterloo station (in London) to Guernsey, and he contended that as the Railway Company had entered into a contract

${ }^{18}$ (1919, C. C. A. 2d) 26r Fed. 897, certiorari denied by the Supreme Court (I920) 25 I U. S. 559 , 40 Sup. Ct. 180.

${ }^{20} 26$ I Fed. at p. 899.

${ }^{20}$ The Loyal (I9r3, C. C. A. 2d) 204 Fed. 930.

${ }^{21}$ (1872) L. R. 8 Ch. App. 24 I. 
with him as a common carrier the limitation of liability statutes did not apply. This contention was, however, rejected. The judgment of Lord Justice Mellish, which was directed to the reasons of policy which led to the adoption of the statutes, has been frequently quoted:22

"It has been thought a matter of public policy to encourage persons to embark their capital in ships by limiting the liability to be incurred by the loss of goods; and this, previously to Lord Campbell's Act, was the principal liability. It was thought expedient to limit the liability, because a ship might carry gold, or goods of great value, and then, from some trifing act of neglect on the part of the master, or on the part of the man steering the vessel, the shipowner might be made sub- ject to enormous liability. On that account the Legislature thought it was for the public advantage that there should be this limit on the liability of the owner."

In Wahlberg v. Young, ${ }^{23}$ the action was brought by the owners of a tow against the owners of a tug for breach of contract, in that the tug failed to perform the towage service carefully, with the result that the tow was damaged. Lord Coleridge, C. J., there said :24

"It was argued unsuccessfully, in The London and Southwestern Railway Company $v$. James, though only faintly, that the case of a breach of contract was not within the 54th section of the Merchant Shipping Act, I862, but if that case had never existed, I should have considered that there was nothing to exclude the case from the limitation of liability given by the statute, merely because the injury arose from a breach of contract. The limitation is to be construed in favour of shipowners, and applies equally whether the damage done be from a breach of contract, or from a simple tort. The navigation of the tug is to be considered in the relation in which it stands to the other vessel, and it may be, and here it must be, admitted that the neglect to obey the order of the pilot was such an improper navigation of the tug, as to produce the disastrous result which ensued. It is true that there may be a breach of the contract to tow which may not be from any improper navigation of the tug; if, whilst it is towing another vessel damage be done to such other vessel, it appears to me to be within sub-section 4 of the 54th Section."

There is little of interest in a review of the decisions, however necessary it may be for a proper discussion of the question on principle.

The law of every maritime country recognizes the right of a shipowner to limit his liability. The justification for that right is that ventures by sea are by their very nature subject to disasters, the liability for which may be thrust upon owners of ships although personally innocent. A shipowner may well be denied the right to limit his liability for claims resting purely upon contract, such as supplies furnished,

Ibid. 252-253.

${ }^{23}$ (1876) 45 L. J. C. P. 783.

"Ibid. 785 . 
repairs made, and so forth. In fact the statutory provision as to contracts has been so whittled away by the courts as to make it of little, if any, consequence. There is, however, a large class of claims which are on the border line between contract and tort. Such claims have their genesis in some negligent act of the shipowners' servants. They are within the letter and spirit of the statute; in essence they are based on tort, not contract. Surely limitation should not be denied, although our forms of procedure allow a suit to be brought for breach of contract, express or implied.

In the recent decisions the extraordinary result is reached that although legally two contracts have the same significance (because the . language used merely states a promise which would otherwise be implied) yet a shipowner who has clothed his undertaking in words is much worse off than one whose obligation arises through a necessary implication in his agreement.

It would seem that the Courts have confused the issue in denying the right to limit in such a case as Pendleton v. Benner Line. ${ }^{25}$ They base their denial of this right upon the ground that the owner may not limit his liability for the breach of a personal contract, relying upon decisions made under the Act of $1884 .{ }^{26}$ But the shipowner does not rely upon that act at all; he is fully protected by the provisions of the Act of 185I. ${ }^{27}$ That statute makes no mention of personal contracts; it is merely a codification of the law of the sea which permits limitation of liability in all cases of loss or damage occurring without the shipowner's knowledge or privity.

It is, of course, true that a shipowner may waive the benefit of his - right to limit liability, and it is not necessary that he use express words to that effect. The Great Lakes Towing Company case ${ }^{28}$ is an example of such an agreement. When the Transportation Company agreed to pay for the work done at fixed rates, it is a possible, though not a necessary, implication that the rates were to be paid irrespective of the success of the salvage services. Another example of such a contract is that contained in many of the bills of lading issued by coastwise lines in which it is stated that the goods are insured against marine risks. By assuming the liability of an insurer the carrier agrees to waive the right to limit its liability. Such a waiver, however, should not be lightly implied. In Pendleton v. Benner Line, ${ }^{29}$ the charter described the ship as "tight, staunch, and strong"-words which have appeared in almost every charter for at least a hundred years and which do no more than state the warranty of seaworthiness which would exist even if the lan-

${ }^{25}$ Supra note 15.

${ }^{2 *}$ Silpra note 7 .

${ }^{27}$ Supra note 4, now Rev. Sts. 1878 , sec. 4283.

${ }^{23}$ Sipra note 12.

${ }^{20}$ Supra note 15. 
guage used were omitted. It would be impossible to base a waiver of the shipowner's right on this alone. And the fact that the agreement is signed by the shipowner personally or by an authorized agent should not influence the result.

It is undoubtedly true that the doctrine of "personal contract" is now fixed in our law. It is unlikely that the Supreme Court will ever recede from a rule which it has several times declared. However this may be, modern conditions necessitate uniformity in the maritime law of all countries, and this may lead to a change in our statutes. Until that takes place it cannot be too urgently emphasized that the ownership of a vessel by individuals is unsafe. Under the recent decisions a shipowner's stake at risk is not limited to his interest in the vessel. He may, though personally blameless, lose his ship and, in addition, be subjected to an overwhelming liability to third persons. The result hardly tends to encourage investment in shipping. 